\title{
Felső nagymetszőfogak avulsiójának kombinált ellátása
}

\author{
Vajda Katalin dr. ${ }^{1}$ - Fekecs Gergő dr. ${ }^{3}$ - Muzsek Zsófia dr. ${ }^{2}$ \\ Pécsi Tudományegyetem, Klinikai Központ, Fogorvostudományi Szak, 'Gyermek- és Ifjúságfogászati Tanszék, \\ Fogszabályozási Részleg, ${ }^{2}$ Fogpótlástani Tanszék, Pécs \\ ${ }^{3}$ FG Dental Fogászati és Szájsebészeti Rendelő, Pécs
}

A szerzök cikküket a Pécsi Tudományegyetem alapitásának 650. évfordulójának tiszteletére ajánlják.

\begin{abstract}
A maradó fogak avulsiója az egyik legsúlyosabb, fogazatot érintő sérülés, ami veszélyeztetheti a páciens életminőségét. Ezért a gyors és helyes beavatkozás nagyon fontos a sérült fog prognózisában. Ilyen esetekben a tüneti kezelés, a végleges funkcionális helyreállítás és a megfelelő rehabilitáció válik fő kezelési céllá. A traumás erő okozhat olyan összetett orális és maxillofacialis sérüléseket, amelyeknek átfogó kezelése nagy kihívást jelent egyetlen fogorvosnak. Jelen esetismertetés kapcsán részletesen áttekintjük a fogazati sérülésből adódó funkcionális helyreállítást és a végleges kezelésig eltelt időszak esztétikai megoldását.

Orv Hetil. 2017; 158(33): 1314-1318.
\end{abstract}

Kulcsszavak: fogazati trauma, traumás fogazati sérülés, avulsio, fogszabályozási kezelés

\section{Combined treatment of avulsion of maxillary central incisors}

Avulsion of the permanent teeth is one of the most serious forms of traumatic dental injuries, which endangers the patients' quality of life. Therefore, the fast and proper treatment is crucial. In this case report we will discuss the supportive and definitive functional treatment and correct rehabilitation. The traumatic force can cause complex oral and maxillofacial injuries, which comprehensive treatment constitutes a major challenge for the dentist. Here we review functional restoration of dental injuries and their definitive aesthetic solution.

Vajda K, Fekecs G, Muzsek Zs. [Combined treatment of avulsion of maxillary central incisors]. Orv Hetil. 2017; 158(33): 1314-1318.

Keywords: dental trauma, traumatic dental injuries, avulsion, orthodontic treatment

(Beérkezett: 2017. június 26.; elfogadva: 2017. július 13.)

\section{Rövidítések}

$\mathrm{CBCT}=$ cone beam computer tomography; HBSS = Hank's balanced salt solution; PDL = periodontalis ligamentum

A dentális traumák számos különböző típusú sérülést okozhatnak, érintve a fogazatot, a dentoalveolaris struktúrát és a környező lágy részeket. Hatféle ficamot (rándulás, subluxatio, extrusio, lateralis luxatio, intrusio, avulsio) és hét töréstípust (traumás infractio, pulpaexpo- zíció nélküli koronatörés, koronatörés pulpaexpozícióval, korona-gyökér törés vagy gyökértörés, alveolustörés, állcsonttörés) különítünk el [1].

Az egyre nagyobb számban előforduló traumás fogazati sérülések közegészségügyi jelentősége nagy, amihez hozzájárulnak az erőszakos búncselekmények, a közlekedési balesetek és a sporttevékenységek. A traumás dentális sérülések erős hatással vannak a gyermekek és a serdülők életminőségére, mert fizikai és érzelmi stresszhatást okozhatnak, valamint negatívan hatnak a szociális kap- 
csolatokra is. A traumás dentális sérülések legmagasabb arányban a 6-10 éves korosztályban fordulnak elő, majd ezt követi a 11-15 éves korcsoport. A páciensek nemi eloszlása azt mutatja, hogy sokkal gyakrabban érintettek a férfiak, mint a nók. Az etiológiai faktorokat figyelembe véve a dentális traumák több mint felét esés okozza. A fogazati sérülések előfordulási gyakoriságában kiugrás figyelhető meg július és szeptember között, közel 90\%uk pedig a felső állcsontot érinti. Leggyakrabban a felső nagymetszők érintettek, majd ezt követi a felső kismetsző. A baleset típusát nézve a leggyakoribb a nem komplikált koronatörés a pulpa megnyílása nélkül, illetve ezt követi a komplikált koronatörés pulpamegnyílással [2].

A traumás dentális sérülések okait öt kategóriába sorolhatjuk: 1. közlekedési balesetek, 2. sportolás közben szerzett sérülés, 3 . esés, 4 . erőszakos cselekmény és 5 . egyéb [3].

Számos tanulmány bizonyítja, hogy az avulsióval járó esetek a legsúlyosabb fogászati balesetek közé tartoznak, a prognózis nagymértékben függ a baleset helyszínén és rögtön azt követően történő ellátástól, továbbá a sérült fog szájon kívül töltött idejének hosszától, valamint hogy az avulsiót követően milyen hatások érték a fogat. A legtöbb esetben a replantáció a választott kezelés, de ez nem mindig végezhető el azonnal. Vannak olyan individuális esetek, amikor a fog replantációja nem javasolt (például súlyos fogszuvasodás vagy fogágybetegség, nem kooperáló páciens, súlyos alapbetegség, mint immunszuppresszió vagy súlyos szívbetegség). A fog replantációjának sikere nagymértékben függ attól, hogy a szájon kívül eltöltött időben milyen közegben tároljuk a fogat. Fontos tudni, hogy a replantált fogaknak nagyon csekély a hosszú távú túlélési esélyük, a későbbiekben lehetséges a fog elvesztése vagy extractiója $[4,5]$.

$\mathrm{Az}$ avulsio előfordulási aránya mindkét nem esetén majdnem azonos. A maradó fogak avulsiója a traumás dentális sérülések 0,5-3\%-a [5].

Amennyiben a periodontalis ligamentumok (PDL) jó állapotban maradnak, úgy újra el tudják látni funkciójukat, különösen akkor, ha a replantáció 15-20 percen belül megtörténik. Ha azonban a szájon kívül töltött idő elhúzódik, akkor a kedvező eredmény esélye csekély. Ilyen esetekben fontos a klinikus számára, hogy ne csak fenntartsa a helyet egy rögzített fogszabályozó készülékkel, hanem javítsa az esztétikát, a formát és a funkciót [5].

A traumás fogazati sérülések, különösen a luxatiók és az avulsio, az alveolaris csont töréséhez vezethetnek, ami viszont a fog elvesztését okozhatja. A traumás alveolaris csonttörések két csoportba sorolhatók. Az első típus egyetlen fogat körülvevő területre korlátozódik. A második típus lehet regionális, amelyet általában könnyebb felismerni, mivel az egész dentoalveolaris szegmens diszlokálódik. A több fogat érintő dentoalveolaris traumák nem gyakoriak, és többnyire súlyos traumás események, például sportolás közben szerzett sérülések, erőszak vagy közlekedési baleset után jelentkeznek $[6,7]$. A felső frontális területen a fogak és az alveolaris csont sérülése súlyos alveolaris gerinchiányt okozhat, ami gerincatrófiát, a felsó állcsont retrognatizmusát és jövőbeli rehabilitációs nehézséget idézhet elő. A fogak és az alveolaris csont elvesztése a fibroticus hegképződéssel együtt hátrányos változásokat okozhat a frontális területen, a rágósíkban, a fogívek egymáshoz viszonyított helyzetében és a formai megjelenésben. Ezek a változások akadályozhatják a rehabilitációt és befolyásolhatják az esztétikát [8]. Az egy fog körüli alveolaris csonttörést nehéz felismerni, hacsak a felette lévő nyálkahártya nem perforált. A tünetek - mint a fájdalom, a harapási eltérés és a fogak mobilitása - további gyanús jelek lehetnek az alveolaris csonttörésre. Pulpanekrózis alakulhat ki az alveolaris törések után az apicalis gyökérrégió közelében $[9,10]$. A proximált alveolaris csont integritását minden olyan esetben meg kell vizsgálni törés gyanúja miatt, ahol avulsiót, luxatiót vagy más fogkárosodást észlelünk [11].

A traumás fogazati sérülések meghatározásakor a helyes diagnózis felállítását a klinikusok végzik képalkotó eljárások segítségével. A sérülések helyes azonosítása szükségszerú az optimális kezeléshez.

A 2D-s röntgenfelvételeknél a hiányzó harmadik dimenzióban található információk különösen fontosak a traumás sérülések diagnosztizálásánál, ahol tisztán kell látni és értelmezni a gyökér angulatióját a corticalis csonthoz, a corticalis csont vastagságát és a gyökerek helyzetét a különböző anatómiai struktúrákhoz, mint például a nervus alveolaris inferior, a foramen mentale és a sinus maxillaris.

A 3D-s CBCT-felvételek a traumás fogazati sérülések diagnosztizálása és ellátása szempontjából elengedhetetlenek [12].

A maradó fogak avulsiójának kezelése összefügg a gyökér (nyitott vagy zárt apex) fejlettségével és a periodontalis ligamentumsejtek állapotával [13-17]. A sejtek állapota a környező médiumtól és a szájüregen kívül töltött idő tartamától függ, különösen a száraz idő veszélyezteti a sejtek túlélését. Hatvan perc vagy annál hoszszabb szárazon töltött idő után a PDL-sejtek nem életképesek. Ezért a fog száraz időtartama, mielőtt replantálták vagy tárolóközegbe helyezték, nagyon fontos a páciens kórelőzményének értékeléséhez [18-20].

A kezelés szempontjából fontos, hogy a klinikus nagyjából megvizsgálja a sejtek állapotát, és a totálisan luxálódott fogat a következő három csoportba sorolja:

- A PDL-sejtek valószínúleg életképesek, azaz a fogat azonnal replantálták a baleset helyszínén vagy nagyon rövid idő elteltével.

- A PDL-sejtek életképesek lehetnek, de veszélyeztetettek. A fogat tárolóközegben (például szövettenyésztő tápközegben, HBSS-ben, sóoldatban, tejben vagy nyálban) tartották, és a teljes száraz idő 60 percnél kevesebb volt.

- A PDL-sejtek nem életképesek. Például, amikor a teljes extraorális száraz idő több mint 60 perc, függetlenül attól, hogy a fogat egy másik tápközegben tároltuk-e, vagy hogy a tárolóközeg fiziológiás-e [21, 22]. 

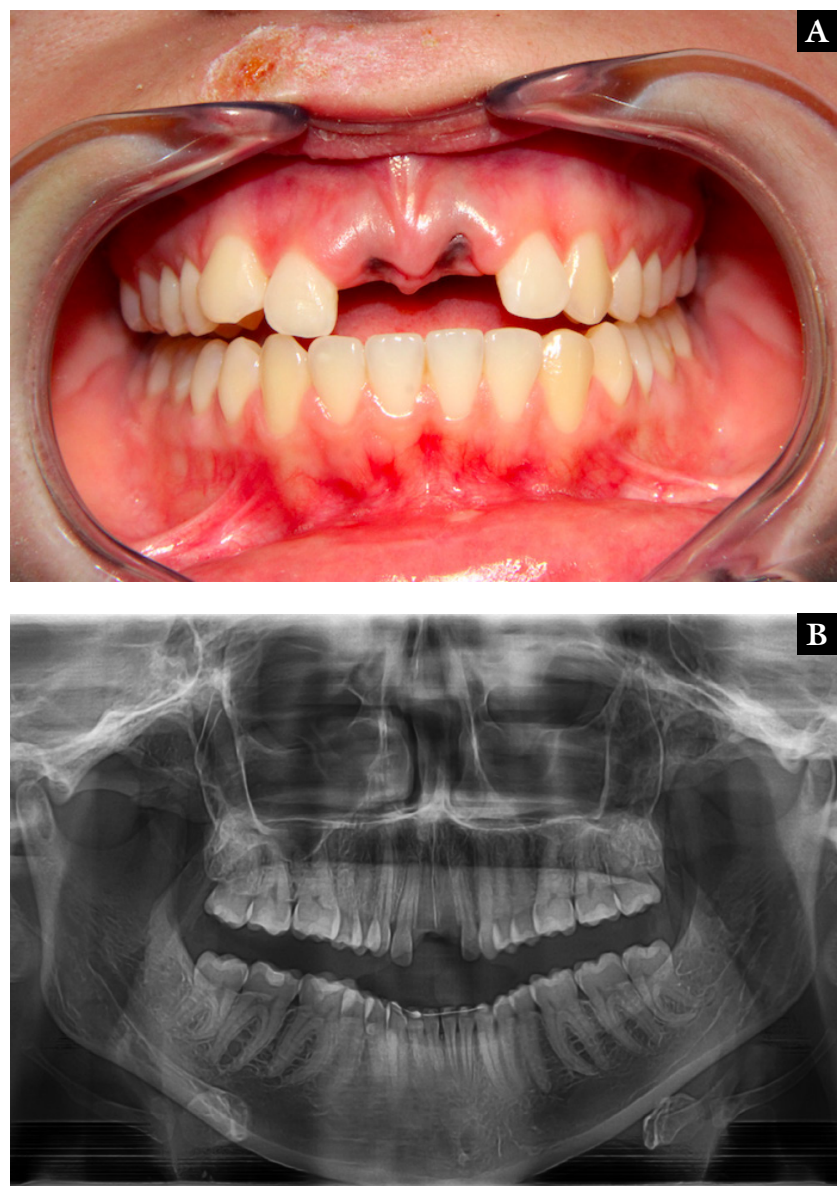

1. ábra

A balesetet követő intraorális fotó (A) és ortopantomogram-felvétel (B). 1.1 és 2.1 fog: totális luxatiót követő állapot, 1.2 fog lateralis luxatio

A szisztémás antibiotikumok adásának indokoltsága a replantáció után kérdéses, mivel az eddigi klinikai vizsgálatok nem igazolták teljes mértékben. A kísérletes vizsgálatok általában pozitív hatásokat mutatnak mind a parodontalis, mind a pulpalis gyógyulásra, különösen helyi beadás esetén. Ezért az antibiotikumokat a legtöbb esetben a fogak replantációja után ajánlják. Ezenkívül a páciens egészségi állapota vagy egyidejü egyéb sérülése indokolhatja az antibiotikum szedését.

Szisztémás beadás esetén a tetraciklin az elsődlegesen választandó szer a páciens életkorának és súlyának megfelelő dózisban a replantációt követő első héten. A maradó fogak elszíneződésének kockázatát figyelembe kell venni a tetraciklin alkalmazása előtt fiatal pácienseknél. Sok országban a tetraciklint nem javasolják 12 év alatti betegeknél. A tetraciklin alternatívájaként penicillin-fenoxi-metil-penicillin (Pen $\mathrm{V}$ ) vagy amoxicillin ajánlott az első héten.

Kísérletes adatok alapján a helyi antibiotikumok (minociklin vagy doxiciklin, $1 \mathrm{mg} 20 \mathrm{ml}$ sóoldatban 5 perc áztatás esetén) jótékony hatást fejtenek ki a pulpalis tér revascularisatiójának és a parodontalis gyógyulás esélyének növelésére, és éretlen fogaknál is alkalmazhatók [23].
A beteget tájékoztatni kell a tetanusz emlékeztető oltás szükségességérôl, ha az avulsiót szenvedett fog érintkezett a talajjal, vagy ha a tetanuszlefedettség nem megfelelő.

\section{Esetismertetés}

Egy 23 éves nő görkorcsolyázás közben elesett. A balesetet követően azonnal jelentkezett a legközelebbi megyei kórház sürgősségi osztályán a felső nagymetszőfogak totális luxatiójával és a felső ajak lágyrész-sérülésével. A sürgősségi ellátás során készült röntgenfelvétel a maxillofacialis terület törését kizárta, de a dentalis trauma további ellátását nem tudták elvégezni. Az elsődleges ellátás során Tetanus injekciót és antibiotikumot (Tabl. Augmentin $1000 \mathrm{mg}$ ) kapott. A páciens a balesetet követố napon jelentkezett klinikánk maxillofacialis ügyeletén, ahol a nem megfelelően (gyufásskatulyában) tárolt fogak visszahelyezése az időfaktor függvényében már nem volt lehetséges. Ezt követően a 1.2 fog extrusiója miatt fennálló traumás okklúzió további ellátásának céljából a klinika fogpótlástani osztályára került (1. ábra).
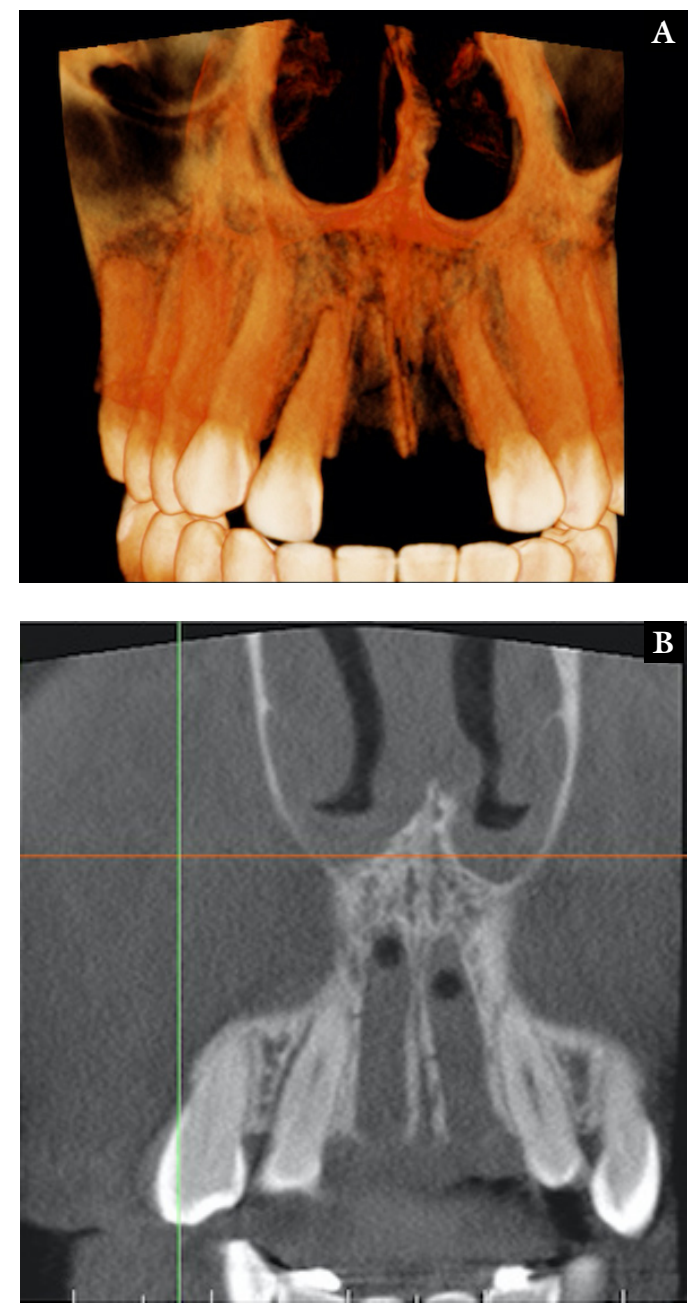

2. ábra (A, B) $\mid$ CBCT-felvétel 

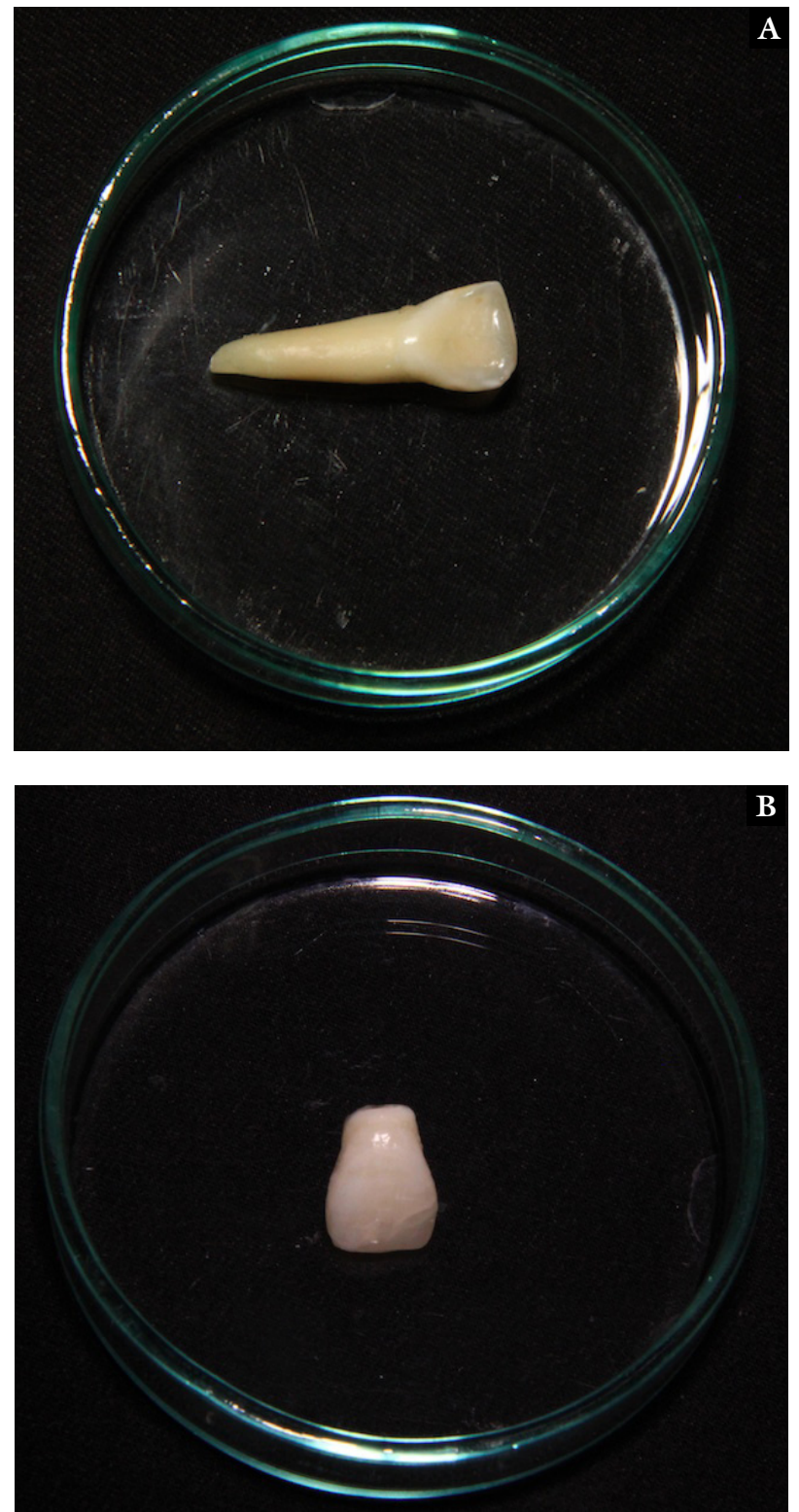

3. ábra $(\mathrm{A}, \mathrm{B}) \mid \mathrm{Az}$ avulsiót és a dekoronálást követő állapot

A sérülés pontosabb megítéléséhez CBCT-vizsgálat készült, amelyen a felső nagymetszők totális luxatiója utáni állapot és az érintett terület processus alveolarisának darabos törése volt megfigyelhető (2. ábra).

A primer ellátás során az 1.1 és a 2.1 fogak gyökereit gyémántfúróval eltávolítottuk, a gingiva lefutását figyelembe véve alakját in situ kialakítottuk, a pulpakamrából az elhalt szöveteket acél gömbfúró segítségével eltávolítottuk, majd nátrium-hipokloritos öblítést és szárítást, valamint savazást és bondozást követően a pulpakamrát folyékony kompozittal (3M Filtek Ultimate) töltöttük fel (3. ábra).

A felső fogívre 1.6-tól 2.6-ig rögzített fogszabályozó készüléket (Dentaurum, Equilibrium Mini 0,018” slot) ragasztottunk (3M Transbond XT), és a jobb esztétika érdekében a brackettek segítségével felhasználtuk az 1.1 és 2.1 fogak koronális részét (4. ábra).

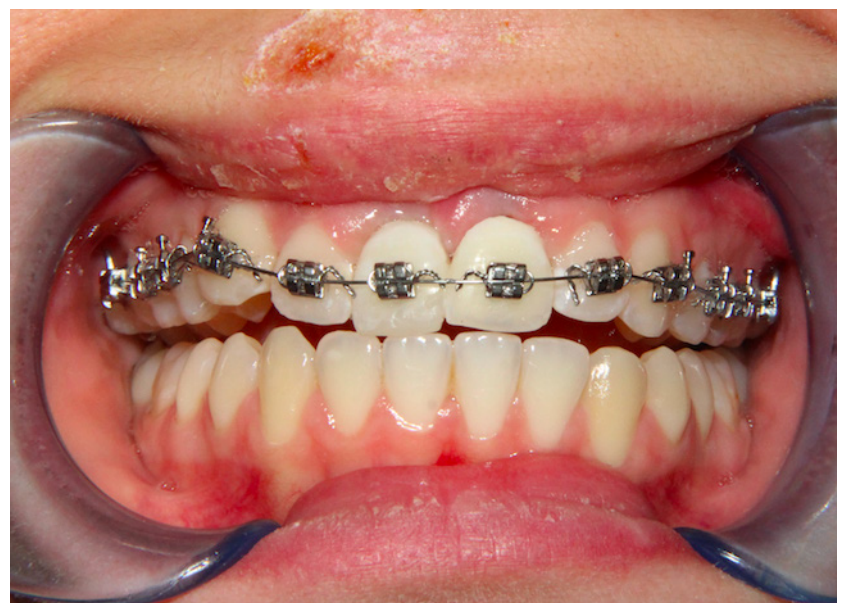

\begin{tabular}{l|l} 
4. ábra & Felső állcsontra felhelyezett rögzített fogszabályozó készülék
\end{tabular}

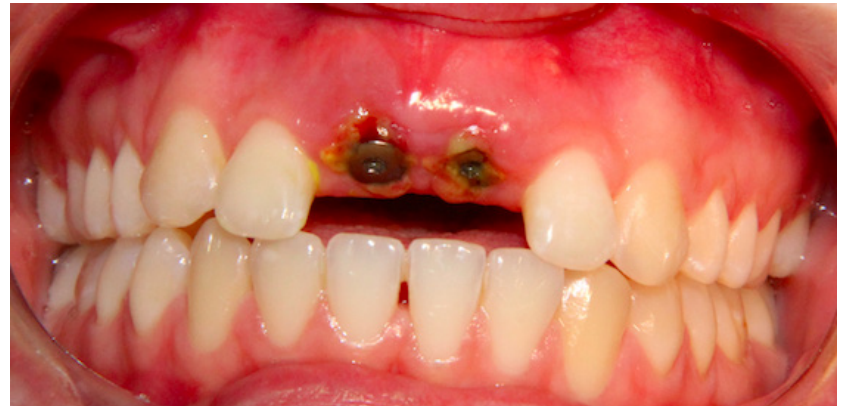

5. ábra | Ínyformázó csavarok behelyezése utáni állapot

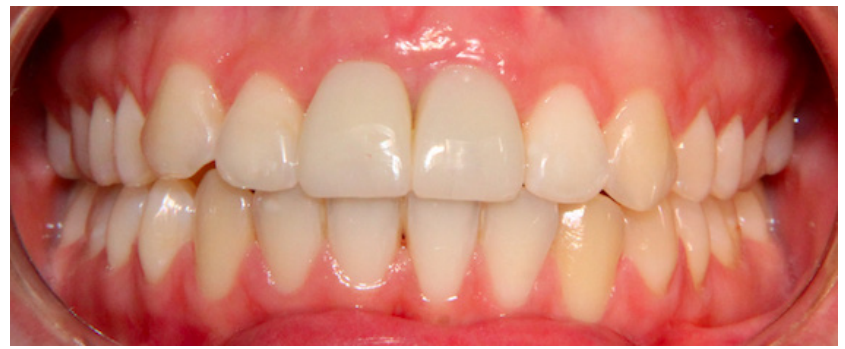

6. ábra | Koronák beragasztása utáni állapot

Két hónap múlva az 1.1 és a 2.1 fogak helyére Straumann BLT Roxolid 3,3 314 mm-es implantátumok és Bio Oss csontpótló, valamint Lyoplant membrán behelyezése megtörtént (5. ábra).

Az 1.2 fognál vitalitásvesztést diagnosztizáltunk, így a későbbiekben gyökérkezelése szükségszerüvé vált. A fogat fogszabályozó készülékkel sikeresen intrudáltuk, ezáltal a korábbi prematur érintkezést megszüntettük.

Hat hónap osseointegrációt követően megtörtént az implantátum felszabadítása. Első lépésben a megfelelő gingivakontúr kialakításának érdekében a páciens számára Straumann NC ideiglenes múcsonkra akrilátkoronát készítettünk. Egy hónapos várakozási időt követően végleges megoldásként Straumann IPS emax anatómiai cirkónium-oxid $15^{\circ}$-os múcsonkot választottunk $3,5 \mathrm{~mm}$ gingivamagassággal, amelyre cirkónium-oxid vázas szóló koronapótlás került (6. ábra). 


\section{Megbeszélés}

Amennyiben egy fog totális luxatio következtében avulsiót szenved, a periodontalis ligamentumok kiszakadnak a processus alveolarisból, így sérülhet a csont folytonossága, és kár keletkezhet a cementrétegben is. A replantáció kellemetlen következményei minimálisak, ha a periodontalis ligamentumok sejtjei életképesek maradnak. A szárazon tartott, dehidratált fog viszont elveszíti a sejtek életképességét. Ennélfogva az avulsio kezelésének fó célja, hogy minimálisra csökkentsük a baleset eredményeként fellépő gyulladás mértékét, és csökkentsük a lehetséges komplikációk veszélyét.

A frontfogak avulsiójának ellátása fiatal páciensek esetén kihívás a fogorvosi szakmának, a legideálisabb kezelési lehetőség során szükség van protetikai, fogszabályozási kezelésre és implantációra [24].

Anyagi támogatás: A közlemény megírása anyagi támogatásban nem részesült.

Szerzői munkamegosztás: A munka a szerzők közös érdeme. A cikk végleges változatát mindhárom szerző elolvasta és jóváhagyta.

Érdekeltségek: A szerzőknek nincsenek érdekeltségeik.

\section{Irodalom}

[1] Lauridsen E, Hermann NV, Gerds TA, et al. Pattern of traumatic dental injuries in the permanent dentition among children, adolescents, and adults. Dent Traumatol. 2012; 28: 358-363.

[2] Guedes OA, de Alencar AH, Lopes LG, et al. A retrospective study of traumatic dental injuries in a Brazilian dental urgency service. Braz Dent J. 2010; 21: 153-157.

[3] Andreasen JO, Andreasen FM, Andersson L. Textbook and the color atlas of traumatic injuries to the teeth. 4 th edition. WileyBlackwell, Oxford, 2007, p. 770.

[4] Tzigkounakis V, Merglová V, Hecová H, et al. Retrospective clinical study of 90 avulsed permanent teeth in 58 children. Dent Traumatol. 2008; 24: 598-602.

[5] Garla BK, Deshmukh S, Murthy PS, et al. Modified esthetic splint design for management of multiple traumatic injuries in children: A case report. J Int Oral Health 2015; 7: 124-126.

[6] Wright G, Bell A, McGlashan G, et al. Dentoalveolar trauma in Glasgow: an audit of mechanism and injury. Dent Traumatol. 2007; 23: 226-231.

[7] Koyuturk AE, Kusgoz A. Multiple dentoalveolar traumatic injury: a case report (3 years follow up). Dent Traumatol. 2008; 24 : el6-e19.

[8] Zahrani AA. Augmentation in two stages of atrophic alveolar bone prior to dental rehabilitation: a case report. J Contemp Dent Pract. 2007; 8: 57-63.
[9] Oikarinen K, Lahti J, Raustia AM. Prognosis of permanent teeth in the line of mandibular fractures. Endod Dent Traumatol. 1990; 6: 177-182.

[10] Kamboozia AH, Punnia-Moorthy A. The fate of teeth in mandibular fracture lines. A clinical and radiographic follow-up study. Int J Oral Maxillofac Surg. 1993; 22: 97-101.

[11] Gutmacher Z, Peled E, Norman D, et al. Alveolar bone fracture: pathognomonic sign for clinical diagnosis. Open Dent J. 2017; 11: 8-14.

[12] Cohenca N, Silberman A. Contemporary imaging for the diagnosis and treatment of traumatic dental injuries. A review. Dent Traumatol. First published: 5 May 2017. doi: 10.1111/ edt.12339. [Epub ahead of print]

[13] Flores MT, Andersson L, Andreasen JO, et al. Guidelines for the management of traumatic dental injuries. I. Fractures and luxations of permanent teeth. Dent Traumatol. 2007; 23: 66-71.

[14] Flores MT, Andersson L, Andreasen JO, et al. Guidelines for the management of traumatic dental injuries. II. Avulsion of permanent teeth. Dent Traumatol. 2007; 23: 130-136.

[15] Flores MT, Andersson L, Andreasen JO, et al. Guidelines for the management of traumatic dental injuries. III. Primary teeth. Dent Traumatol. 2007; 23: 196-202.

[16] Petrovic B, Markovic D, Peric T, et al. Factors related to treatment and outcomes of avulsed teeth. Dent Traumatol. 2010;26: 52-59.

[17] Trope M. Avulsion of permanent teeth: theory to practice. Dent Traumatol. 2011; 27: 281-294.

[18] Andersson L, Andreasen JO, Day P, et al. Guidelines for the management of traumatic dental injuries: 2. Avulsion of permanent Teeth. Pediatr Dent. 2016; 38: 369-376.

[19] Holan, G. Replantation of avulsed primary incisors: a critical review of a controversial treatment. Dent Traumatol. 2013; 29: 178-184.

[20] Panzarini SR, Gulinelli JL, Poi WR, et al. Treatment of root surface in delayed tooth replantation: a review of literature. Dent Traumatol. 2008; 24: 277-282.

[21] De Souza BD, Bortoluzzi EA, da Silveira Teixeira C, et al. Effect of HBSS storage time on human periodontal ligament fibroblast viability. Dent Traumatol. 2010; 26: 481-483.

[22] Pohl Y, Filippi A, Kirschner H. Results after replantation of avulsed permanent teeth. II. Periodontal healing and the role of physiologic storage and antiresorptive-regenerative therapy. Dent Traumatol. 2005; 21: 93-101.

[23] Andreasen JO, Storgård Jensen S, Sae-Lim, V. The role of antibiotics in preventing healing complications after traumatic dental injuries: a literature review. Endodontic Topics 2006; 14: 80-92.

[24] Ferreira MM, Ferreira HM, Botelho F, et al. Autotransplantation combined with orthodontic treatment: a case involving the maxillary central incisors with root resorption after traumatic injury. Restor Dent Endod. 2015; 40: 236-240.

(Vajda Katalin dr., Pécs, Dischka Gy. u. 5., 7621 e-mail: drvajdakata@gmail.com) 